\title{
MARKETING COST AND VALUE CHAIN ANALYSIS OF OIL PALM FRUIT PROCESSING IN IMO STATE, NIGERIA
}

\author{
Nwankwo, O.O. and Nwosu, U.L. \\ Department of Agricultural Economics, Extension and Rural Development, \\ Imo State University Owerri, Nigeria \\ Corresponding author email: drolivernwankwo@gmail.com
}

\begin{abstract}
Evaluation of marketing cost and value addition to oil palm fruit processing and marketing in Imo State was carried out. Agricultural produce marketing channels are superfluous with intermediaries who have been opined to add no value. The study assessed the cost and return, established the net profit and values added along the marketing channel of oil palm fruit. Stratified, random and purposive sampling techniques were used in selecting 108 individual processors, 6 processing firms and 108 marketers. Three sets of questionnaire were administered, one to each set of respondents to generate data. Means, percentages, cost and return and regression analyses were employed in analyzing data. Results show a profitable business, simple marketing channels, value addition to product line by intermediaries, net profit of $\$ 39.90$ for processors, and $\$ 81.80$ for firms per $1000 \mathrm{FFB}$; wholesale and retail marketers made $\mathrm{N} 39.20$ and $\$ 41.50$ per 1000 litres of oil respectively. Socio-economic characteristics had significant effect on net income of respondents, with gender, marital status, education and experience contributing significantly at $1 \%$ probability. The study recommended joint effort of private and public stakeholders, to provide improved facilities and policies, that will enhance oil palm fruit processing and marketing to reduce cost and increase net income.
\end{abstract}

Keywords: Processing, value chain, intermediaries, utility value and change of ownership. https://dx.doi.org/10.4314/jafs.v16i1.9

\section{INTRODUCTION}

Agricultural produce marketing encompasses all the activities involved in getting a farm produce ready to satisfy the taste of its consumers. Adekanye (1998) defined agricultural marketing as sum total of all business activities involved in the movement of agricultural commodities from farmers to places of consumption. Nwankwo (2010) added that it takes a number of marketing activities to actualize a marketing process.

The value chain of an agricultural product involves a number of marketing functions at different stages of the marketing channel. These functions often include processing, storing, transporting, 
selling and transfer of ownership. Value chain costs include all expenses incurred along the different stages of the marketing channel as marketing functions are performed. The monetary value of agricultural produce increases as the product passes through different intermediaries who add one value or the other. This is measured from total sales less total input cost of performing the functions which add the values. The physical utility value addition involves changes to the desired form, storage until when needed, movement to places where needed, and selling to transfer ownership to satisfy the utility need of the consumer. Ahmed (2001) defined value chain as a structure of physical, economic and social transactions between individuals and organizations engaged in a raw material transformation into cherished end products. He further added that the value chain of an agricultural produce is the marketing channel along which values are added at different stages of the marketing process by intermediaries. However Mohammed (2007) submitted that the channel of agricultural produce marketing from producer to consumer often involves long chain of superfluous intermediaries without much value addition and that this reduces the marketing profit and marketing efficiency of produce.

Some constraints occur along the marketing channel. These reduce profitability and marketing efficiency. Some of them compound over time hence the need for continuous studies to update their solutions. Sango (2010) highlighted that value chain analysis examines the various activities of processing and marketing performed by intermediaries along the chain line, how they interact and add value to the product line. Value chain analysis facilitates the identification of constraints to oil palm industry growth and its competitiveness with other industries. It leads to understanding of the relationship and linkages among producers, buyers, suppliers and all market intermediaries (PIND, 2011).

Marketing is the activity of identifying and satisfying needs and wants of consumers. Kotler (1997) saw marketing as a social and managerial process by which individuals and groups of individuals obtain what they need through creating, offering and exchange of products of value. Agricultural marketing is a vital occupation in Imo State. Oil palm is an important tree crop in the State. Palm oil is the principal product of the oil palm industry (Nwankwo and Ibemere, 2013). Palm oil marketing is a major source of employment and income among the rural communities of Imo State. Ahmed (2001) informed that palm fruit processing provides direct and indirect employment among numerous people involved in the processing and marketing. Processing is an activity of agricultural produce marketing channel. Processing of oil palm fruit according to FAO (2005) is defined as a process by which palm fruit is transformed into palm oil and kernel through threshing or stripping, sterilization, milling and digesting, pressing and clarification. It transforms the low value palm fruit to value added palm oil. Oil palm fruit processing in the study area involves traditional methods encompassing little use of improved technologies, and the fairly largely mechanized processing which involves greater use of improved local technologies. Many individuals embark on the traditional method of processing 
with little adoption of improved technologies, while the semi-mechanized processors make more use of improved local technologies. Jalam et al. (2002) suggested that oil palm fruit processors should embrace well integrated capital intensive, high volume and high rate extraction methods in their processing. Palm oil processing in rural Nigeria and Ghana are however not highly mechanized but is operated with only improved technology equipment locally manufactured (Ayodele, 2010). The situation is same in the study area.

The study evaluated the marketing costs and value chain addition to oil palm fruit processing and marketing in Imo State. It specifically assessed the socio-economic characteristics of processors and marketers, examined the sources of palm fruits, and technologies used in processing, and established the marketing activities carried out by intermediaries. It also established marketing activities and strategies of oil palm fruit processing and the marketing channels of the six processing firms. Cost and returns of processors and marketers were calculated. The utility and monetary values added at different stages of the marketing process were established. Constraints to palm fruit processing and palm oil marketing were indentified.

\section{MATERIALS AND METHOD}

The study was carried out in Imo State, Nigeria. The State has twenty seven Local Government Areas (LGAs) and three agricultural zones. The zones are Orlu, Owerri and Okigwe Agricultural Zones. A list of three highest palm oil producing LGAs from each zone was obtained from the office of the Agricultural Development Programme (ADP), Owerri. These LGAs were used for the study. They include; Oru West, Isu and Ideato North for Orlu Zone; Ohaji/Egbema, Mbaitoli and Ngor Okpala foe Owerri Zone and Isiala Mbano, Ihitte Uboma and Onu Imo for Okigwe Zone. A list of fifteen individual oil palm fruit processors was also obtained from the ADP office, for each of the LGAs. This gave a sample frame of 135 processors. A presurvey questionnaire established that each of them processed an average of 1000 fresh fruit bunch per week. A random sampling of 12 respondents from each of the nine LGAs gave a sample size of 108 respondents. Data were collected on the cost and return of processing 1000 FFB. A sample size of 108 marketers was also obtained through the same procedure. A list of 6 processing firms was obtained from each zone, giving a total of 18 firms. Two (2) firms were randomly sampled from each zone to give 6 processing firms.

Three sets of questionnaire were used in data collection. One set was for individual processors, another for processing firms and the other for marketers. The questionnaire was administered by trained enumerators in each sampled LGA. Questionnaire to individual processors and marketers sought information on socio-economic characteristics, inputs used, costs and sources of input, output and marketing channels, and revenue realized. Questionnaire to processing firms, sought information on inputs and their sources, extent of mechanization, output and the marketing 
channels, costs of input items, and revenue from output. Data collected were based on processing 1000 FFB (fresh fruit bunch) and marketing of 1000 litres of palm oil.

The analytical tools used include means, frequencies, percentages and cost and return analysis. Return on investment (ROI) and marketing efficiency were calculated. An ordinary least square multiple regression analysis was used to test the hypothesis that the socio-economic characteristics had no significant effect on the net income of processors and marketers. Four functional forms (Linear, Semi-log, Double log and Exponential) were tried and the model that gave the best fit was used for analysis. The regression model was stated as:

$\mathrm{Y}=\mathrm{f}\left(\mathrm{X}_{1}, \mathrm{X}_{2}, \mathrm{X}_{3}, \mathrm{X}_{4}, \mathrm{X}_{5}, \mathrm{e}\right)$

Where; $\mathrm{Y}=$ net income

$\mathrm{X}_{1}=$ gender $($ male $=1$, female $=2)$

$\mathrm{X}_{2}=$ marital status ( married $=1$, single $=0$ )

$\mathrm{X}_{3}=$ age (no of years)

$\mathrm{X}_{4}=$ number of years in school

$\mathrm{X}_{5}=$ number of years in business

$\mathrm{e} \quad=\quad$ error term

\section{RESULTS AND DISCUSSION}

\section{Socio-economic characteristics of processors and marketers}

Table 1 shows the socio-economic characteristics of the respondent's-oil palm fruit processors and palm oil marketers. It shows that $63 \%$ of the processors were females and $37 \%$ were males, while $60 \%$ of the marketers were females and $40 \%$ were males. This shows that more females than males were involved in palm oil business in the study area. This agrees with the observation of Adamu et al. (2012) that women were more prominent in palm oil extraction activities in Afijio LGA of Oyo State, Nigeria. Ofosu-Budu and Sarpong (2013) reported that small scale palm oil processing and marketing were dominated by women working as groups or individuals in Ghana. Nwankwo (1990) observed that women performed up to 58.9\% of traditional palm fruit processing activities, while Ugwuoke et al. (2004) reported that women were more highly involved in palm oil commercialization process than men.

The result also shows that $81.5 \%$ of processors and $84.3 \%$ of marketers were married, while $56.5 \%$ of processors and $64.8 \%$ of marketers were within the age of $41-50$ years. These showed that they were in their middle age and are likely to contribute more effectively to family welfare and general economic growth. The mean age of the respondents was established as 43.25 years for processors and 42.15 years for marketers. This reveals that majority of the respondents were of middle age class who can perform palm oil extraction and marketing activities more 
profitably. The result agrees with the findings of Sani et al. (2007) and Nurudeen (2012) who noted that farmers within 41-50 years are very active in business.

Table 1 show that $69.4 \%$ among the processors and $74.2 \%$ of marketers had secondary school education while $24.1 \%$ of processors and $13.9 \%$ of marketers had primary school education. A smaller proportion of respondents (6.5\% of processors and $12.0 \%$ of marketers) had tertiary education. Educational attainment impacts positively on business as it enhances business skills. Nurudeen (2012) had reported that level of education enhances business skills. The average business experience of respondents was 21.45 years for processors and 21.56 years for marketers.

\section{Sources of palm fruits to processors}

Eighty six individual processors $(76.3 \%)$ reported that most of the palm fruits they processed were purchased fresh fruits bunch (FFB), while fifty four respondents (48.9\%) obtained most of the fruits from their personal farms- wild palm grooves and palm plantations. The rest of their fruits came from other sources (Table 2). Only eighteen respondents $(16.67 \%)$ reported that most of their fruits came from leasing palm estates. Some respondents obtained fruits from various sources.

The source of fresh fruit bunches (FFB) for the six sampled processing firms are shown in Table 3. All the firms (100\%) obtained some of their FFB by purchases. Four firms (66.7\%) obtained fruits from their farms - palm grooves and palm plantations, while three firms or $50 \%$ obtained from leased palm grooves and plantations.

Table 4 reveals the extent of palm fruit processing activities mechanized by the sampled processing firms. It shows that two out of the seven listed operations of palm fruit processing were not mechanized by any firm. These were bunch reception and nut recovery. Fruit digestion and fruit pressing were mechanized by all firms, showing $100 \%$ mechanization of the two activities. The table shows the rate at which each firm mechanized the processing operations. Three firms recorded higher mechanization rate of $57.1 \%$ than others, while two firms mechanized only $42.9 \%$ of the operations. The least mechanizing firm, Clifford and Sons Enterprise mechanized only two operations, $28.6 \%$ mechanization rate. Out of the seven listed operations only five were mechanized, showing a general mechanization rate of $71.4 \%$.

\section{Functions of intermediaries along the marketing chain}

A number of intermediaries were found along the oil palm fruit marketing chain (Table 5). In some cases they performed similar functions. The intermediaries found along the oil palm fruit marketing chain in the study area include processors, wholesalers and retail marketers. It shows 
that all the 108 processors or $100 \%$ transformed oil palm fruit into palm oil thereby contributing to form utility to meet consumer`s preference. Ninety eight (98) processors or $90.7 \%$ in addition stored some palm oil for sale on later days thereby contributing to time utility. About $88 \%$ of processors carried their palm oil to markets or to places where they were required by consumers. The table shows that all respondents - processors and marketers engaged in price negotiation and sales for the purposes of actualizing change of ownership. All marketers were involved in the functions of storage, distribution, negotiation for purchase and sale of oil, while all processors were only involved in processing, storing, negotiation and sale of oil. It was observed that wholesale marketers and retailers performed identical functions, though their scales of operations may differ.

\section{Sales of palm oil by processors}

Individual processors sold some quantities of oil directly to different channel members. Some quantities were sold immediately at the farm gate while others were sold after storage. Table 6 shows buyers of palm oil from individual processors at the farm gate. It shows that 106 processors or $98.1 \%$ sold to retailers, while 78 processors or $72.2 \%$ sold directly to consumers, and 66 processors or $61.1 \%$ sold to wholesalers. Seventy eight processors had direct or simple marketing channel by selling directly to consumers. The sales to retailers and wholesalers may develop into more complex marketing channels.

Figure 1 shows the marketing channels of individual processors. Some sold part of their oil directly to consumers, some to retailers and others to wholesalers. The retailers who bought directly from producers sold to consumers. The wholesalers who bought from producers sold part of their oil to retailers, who then sold to consumers. Part of their oil was sold directly to consumers.

The six processing firms developed different marketing channels. Fig. 2 shows the different channels through which they sold their palm oil. The firms sold to consumers, retailers and wholesalers. Some wholesalers sold to other wholesalers as well as retailers, some wholesalers sold only to retailers who in turn sold to consumers. Some wholesalers who were bulking large quantities of oil bought from producing firms, other wholesalers and from retailers, and then sold to consumers, some of whom may be industrial users.

It is observed that the products of the firms were not involved in long marketing channels. All marketing intermediaries added both utility value and monetary value along the oil palm fruit marketing value chain. They therefore did not have superfluous intermediaries. The result disagrees with the findings of Mohammed (2007) that the channel of agricultural produce marketing involves a long chain of intermediaries without much value addition. 


\section{Cost and return of processing $1000 f f b$ by individual oil palm processors}

The average cost and return of processing 1000 fresh fruit bunch (FFB) which is approximately 6.5tonnes by the individual processors is presented on Table7. The table shows that the total revenue was estimated as 288,603 , while the total cost was estimated as $\$ 248,700$. This gave a net income of 39,903 per 1000FFB. With this net income, the return on investment (ROI) was established as 0.16 per 11.00 .

\section{Cost and return of processing $1000 \mathrm{ffb}$ by each processing firm.}

Table 8 shows the average cost and return of processing 1000FFB by each of the six processing firms. The total revenue was calculated as $\$ 325,593$, while the total cost was calculated as $\$ 243,800$. This gave a net profit of $\$ 81,793$ per 1000FFB (Table 8). The ROI was calculated as $¥ 0.34$ per 1.00 . The analysis shows that processing firms had higher net profit of $\$ 81,793$ than the individual processors who had $\$ 39,903$ on the 1000 processed FFB. This gave a profit margin of 41,390 to the firms.

\section{Cost and return of palm oil marketing}

Two groups of marketers were identified along the marketing channels of palm oil in the study area. They are wholesale and retail marketers. They were assessed based on marketing 1000 litres of palm oil each (Table 9). The table shows average total revenue of $\$ 190,000$ for wholesalers and $\$ 200,000$ for retailers. The 1000 litres of oil cost wholesalers $\$ 140,000$ at $\mathrm{N} 140$ per litre, while the cost of the same volume of oil to retailers was N150, 000 at $\mathrm{N150}$ per litre. Other variable cost items brought the average total variable cost for wholesalers to $\$ 148$, 600 and that of retailers to $\mathrm{N} 156,850$. The total fixed cost for wholesalers was $\mathrm{N} 2$, 200, while that of retailers was $\$ 1,650$. These brought the total marketing cost of wholesalers to $\$ 150,800$ and that of retailers to $\$ 158,500$. Their net revenues were $\$ 39,200$ and $\$ 41,500$ respectively. Marketing efficiency of wholesalers was calculated as $79.4 \%$, while that of retailers was $79.3 \%$. The implication is that cost of marketing took $79.4 \%$ of total revenue of wholesalers and $79.3 \%$ of the retailers. Retailers therefore had a profit margin of \#2,300 higher than wholesalers per 1000 litres of oil marketed.

\section{Effects of socio-economic characteristics of respondents on net returns}

Regression analysis was applied to assess if the socio-economic characteristics of respondents had significant effect on their net income. Four functional forms of the regression model were tried to assess the effects. Table 10 shows the results of the regression model on individual processor's net income. Semi-log model was considered to have the best fit, and was used for analysis. Though linear $\log$ model had higher $\mathrm{R}^{2}(0.551)$ and higher F-ratio (25.013) than semi$\log$ model which has $\mathrm{R}^{2}$ of 0.441 and F-ratio of 16.103 , yet semi log model was preferred for Journal of the Faculty of Agriculture and Veterinary Medicine, Imo State University Owerri website: www ajol.info 
analysis because it had four independent variables which made significant contributions to net income, while linear log model had two.

Gender $\left(\mathrm{X}_{1}\right)$ made positive and significant contribution to net income in favour of females. The contribution was statistically significant at $1 \%$ level of probability. The result agrees with the findings of Adamu et al. (2012) who observed that women were more prominent in palm oil extraction activities than men. The situation may be attributed to the fact that women are more disposed to the more mild tasks of traditional palm oil extraction in their traditional homes than men who take to other more tasking jobs, even away from their traditional homes for more remuneration.

Marital status $\left(\mathrm{X}_{2}\right)$ had positive and significant contribution to net income. This was at $1 \%$ level of probability. The situation may be attributed to the fact that married respondents get assistance from their spouses. The assistance helps them to carry out operations more timely and effectively. Age $\left(\mathrm{X}_{3}\right)$ made significant and positive contribution to net income at $1 \%$ probability. The contribution may be attributed to the fact that the average age of the processors was 43.25 years. According to Nurudeen (2012) farmers within 41-50 years are very active in business. Education $\left(\mathrm{X}_{4}\right)$ also made positive and significant contribution at $1 \%$ probability. This is because according to a priori expectation education impacts positively on business performance. Nurudeen (2012) also observed that education enhances business skills.

Experience $\left(\mathrm{X}_{5}\right)$ was found to have made positive but no significant contribution to net income. The non-significance of its contribution may stem from the fact that most respondents were middle aged, as indicated by the mean age, and may not have acquired long experience to influence net income significantly. The F-ratio which determines the overall significance of a regression model was significant at $1 \%$ level of probability. This led to the rejection of the null hypothesis that socio-economic characteristics of the respondents had no significant effect on net income. The alternative was therefore accepted.

Table 11 shows the results of the four functional forms of the regression model tried to assess the effects of socio-economic characteristics of palm oil marketers on their net income. It shows that double - log form has two independent variables which made significant contributions to net income, while only one variable made significant contribution in other models. It shows that while exponential-log has $\mathrm{R}^{2}, 0.577$ and F-ratio 27.773 double - $\log$ has $\mathrm{R}^{2}$ of 0.572 and F-ratio 27.264 and was chosen as having the best fit for analysis. This is because double-log form has two variables making significant contributions to net income while exponential- log form has only one.

Gender $\left(\mathrm{X}_{1}\right)$, marital status $\left(\mathrm{X}_{2}\right)$ and age $\left(\mathrm{X}_{3}\right)$ made negative, but no significant contributions to net income. Education $\left(\mathrm{X}_{4}\right)$ and experience $\left(\mathrm{X}_{5}\right)$ made positive and significant contributions to 
net income at $1 \%$ probability. Education contributed according to a priori expectation because it enhances business skills. This is in line with Nurudeen's finding in 2012. Experience has positive effect according to a priori expectation. Experience in a particular business enhances performance, output and income in that business.

The F-ratio was significant at $1 \%$ probability for individual processors and marketers leading to the rejection of the null hypotheses that the socio-economic characteristics of respondents had no significant effect on their net income.

\section{CONCLUSION}

It is concluded that oil palm fruit processing and marketing is profitable in the study area. Superfluous intermediaries were not identified. Each intermediary added utility and monetary value to the value chain. Individual processors had net profit of $\$ 39,900$, while processing firms had net profit of $\$ 81,793$ per 1000FFB processed, while wholesalers and retailers had net profit of $\$ 39,200$ and $\$ 41,500$ respectively per 1000FFB of palm oil marketed. The paper recommends joint effort of private and public stakeholders to provide improved facilities and policies to enhance oil palm fruit processing and palm oil marketing to reduce cost and increase net income. 


\section{REFERENCES}

Adamu,C.O., Apata, O.M. and R.A. Oyeyinka (2012). Processors awareness and utilization of improved palm oil production technology in Oyo State, Nigeria. Journal of Rural Sociology, 13:1-6.

Adekanye, T.O. (1998) "Marketing" Readings in Agricultural marketing (ed) T.O. Adekanye Longman Nigeria, P1.

Ahmed, S.A. (2001). "Agriculture and food security in Nigeria", A paper presented at a forum on Agriculture and Food Security Council Chambers, Minna, Niger State, $10^{\text {th }}-12^{\text {th }}$ February 2001.

Ayodele, T.A. (2010) "Analysis of palm oil and economic development in Nigeria and Ghana" Recommendation for the World Bank's 2020 Palm Oil Strategy, Pp 35-44.

Brown, E. and M.F. Jacobson (2009). Sustainability of smallholder palm oil production in Indonesia. International Journal of Agriculture, Food, Environment and Extension, 4(1): 46-49.

F.A.O. (2005) Global Forest Resources Analysis Update. FAO Rome Agricultural Series No. 36.

Jalam, B.S., Ariffion, D. and K.W. Chain (2000) "Malaysia Contributions to improving the value and use of palm oil through modern technologies". Burotrop Bulletin, No 19, P25.

Kotler, P. (1997) Marketing Management: Analysis, planning, implementation and Control.

Prince Hall International, New Jersey p.9.

Mohammed, J. (2007) "Problems and issues in marketing: Agriculture Marketing Development in Ethopia". International Livestock Institute Report, Pp 34-67.

Nurudeen, A.J. (2012) Economic and social characteristics of registered poultry egg producers in Ilurin, Kwara State, Nigeria. Russian Journal of Agricultural and Social-Economic Sciences, 11(11):20-24.

Nwankwo, O.O. (2010) "Gross margin analysis of mechanized processing of selected industrial cassava products in Southeast Nigeria". Unpublished Ph.D. Thesis, Imo State University Owerri, Nigeria.

Nwankwo, O.O. and I.A. Ibernere, (2013). Analysis of the efficiency of hydraulic hand press and motorized press methods of palm oil extraction in Ohaji/Egbema LGA of Imo State, Nigeria. International Journal of Applied Research and Technology, 2(4): 18-25.

Ofosu-Budu, K. and D. Sarpong (2013) "Oil palm industry growth in Africa: a value chian and smallholders study for Ghana" Rebuilding West Africa's Food Potential (ed) A. Elbehri FAO/FAD.

Partnership Initiative in the Niger Delta (PIND) (2011). A report on palm oil value chain analysis in the Niger Delta.

Journal of the Faculty of Agriculture and Veterinary Medicine, Imo State University Owerri website: www ajol.info 
Sanogo, I. (2010). "Market value chain analysis of food commodity" World Bank Food Program and Food Security, 2:34.

Sani, R. M., Musa, S.A., Darieji, M.I. , Yakasai, M.T. and O. Ayodele (2007). Cost and return analysis in poultry production in Bauchi and Gombe Metropolis Area, Continental Journal of Agricultural Economics, 1:14-19.

Ugwuoke, F.O., Odurukwe, S.N. and I.C. Oguamanam (2004). Roles of impacts of oil palm commercialization on intra-house dynamics in Imo State, Nigeria. Journal of Technology Education in Nigeria,9(2): 14-24 


\section{APPENDIX}

Table 1: Socio-economic characteristics of oil palm fruit processors and palm oil marketers

\begin{tabular}{lllll}
\hline $\begin{array}{l}\text { Socio-economic } \\
\text { characteristics }\end{array}$ & Frequency & Percentage & Frequency & Percen \\
\hline & & & & \\
Gender & 40 & 37.0 & 43 & 40 \\
Male & 68 & 63.0 & 65 & 60 \\
Female & $\mathbf{1 0 8}$ & $\mathbf{1 0 0}$ & $\mathbf{1 0 8}$ & $\mathbf{1 0 0}$ \\
Total & & & &
\end{tabular}

\section{Marital Status}

Single

Married

2

88

Divorced

Widowed

Total

\section{Age (Years)}

21-30

31-40

2

40

1.9

1.9

81.5

4.6

13

12.0

100

12

91

3

2

108

11.1

84.2

2.8

1.9

100

41-50

51-60

61

5

Total

108

Mean

43.25

\section{Level of Education (Years)}

Primary Education

Secondary Education

Tertiary Education

Total

75

7

108

\section{Business Experience}

\section{(Years)}

1-10

11-20

10

20

21-30

48

31-40

30

Total

108

21.45

24.1

15

80

13

6.5

100

108

5.6

24.1

64.8

5.6

100

42.15

6
26

70

6

100

Mean

Source: Field Survey, 2017
9.3

18.5

44.4

27.8

100
13.9

74.2

12.0

100

Journal of the Faculty of Agriculture and Veterinary Medicine, Imo State University Owerri website: www ajol.info 
Volume 16 Number 1, April 2018 pp. 107-125.

Table 2: Sources of palm fruits to individual processors

\begin{tabular}{llll}
\hline Sources & Frequency & Percentage $(\%) *$ & Rank \\
\hline Purchase from market & 86 & 76.3 & $1^{\text {st }}$ \\
Personal farm & 54 & 48.9 & $2^{\text {nd }}$ \\
Leasing & 18 & 16.7 & $3^{\text {rd }}$
\end{tabular}

Source: Field survey, 2017

*Multiple responses recorded

Table 3: Sources of palm fruits to processing firms

\begin{tabular}{llll}
\hline Processor firms & Purchase & Personal farm & Leasing \\
\hline Ojike Mill & $\checkmark$ & $\checkmark$ & X \\
Keleson Enterprises & $\checkmark$ & X & $\checkmark$ \\
James Oil Mill & $\checkmark$ & $\checkmark$ & $\checkmark$ \\
Okoro and Sons Enterprise & $\checkmark$ & X & X \\
Ejike Mil & $\checkmark$ & $\checkmark$ & $\checkmark$ \\
Clifford and Sons Enterprises & $\checkmark$ & $\checkmark$ & $\checkmark$ \\
Total & 6 & 4 & 3 \\
\% of Respondents & 100 & 66.7 & 50 \\
\hline
\end{tabular}

$\checkmark \quad$ : Source of Palm fruit

Source: Field survey, 2017

Table 4: Extent of oil palm fruit processing activities mechanized by the sampled firms

\begin{tabular}{|c|c|c|c|c|c|c|c|}
\hline Activities & Ojike mil & $\begin{array}{l}\text { Keelson } \\
\text { Enterpris } \\
\text { e }\end{array}$ & $\begin{array}{l}\text { James } \\
\text { Oil } \\
\text { Mill }\end{array}$ & $\begin{array}{l}\text { Okoro } \\
\text { and } \\
\text { Sons Ent }\end{array}$ & $\begin{array}{l}\text { Ejike } \\
\text { Mill }\end{array}$ & $\begin{array}{l}\text { Clifford } \\
\text { and sons } \\
\text { Ent }\end{array}$ & $\begin{array}{l}\text { Mechanized } \\
\text { firms }\end{array}$ \\
\hline Bunch reception & $\mathrm{X}$ & $\mathrm{X}$ & $\mathrm{X}$ & $\mathrm{X}$ & $\mathrm{X}$ & $\mathrm{X}$ & - \\
\hline Bunch threshing & $\checkmark$ & $\checkmark$ & $\checkmark$ & $X$ & $\checkmark$ & $\mathrm{X}$ & 4 \\
\hline Fruit boiling & $\checkmark$ & $X$ & $\checkmark$ & $\mathrm{X}$ & $\checkmark$ & $\mathrm{X}$ & 3 \\
\hline Fruit digestion & $\checkmark$ & $\checkmark$ & $\checkmark$ & $\checkmark$ & $\checkmark$ & $\checkmark$ & 6 \\
\hline Fruit pressing & $\checkmark$ & $\checkmark$ & $\checkmark$ & $\checkmark$ & $\checkmark$ & $\checkmark$ & 6 \\
\hline Nut recovery & $X$ & $X$ & $X$ & $X$ & $\mathrm{X}$ & $\mathrm{X}$ & - \\
\hline Oil clarification & $\mathrm{X}$ & $\mathrm{X}$ & $\mathrm{X}$ & $\checkmark$ & $\mathrm{X}$ & $\mathrm{X}$ & 2 \\
\hline No mechanized & 4 & 3 & 4 & 3 & 4 & 2 & \\
\hline$\%$ mechanized & 51.1 & 42.9 & 57.1 & 42.9 & 57.1 & 28.6 & \\
\hline Total no of activities & 7 & & & & & & \\
\hline Total no mechanized & 5 & & & & & & \\
\hline Gen mechanization rate & $71.4 \%$ & & & & & & \\
\hline
\end{tabular}

Journal of the Faculty of Agriculture and Veterinary Medicine, Imo State University Owerri website: www ajol.info 
Volume 16 Number 1, April 2018 pp. $107-125$.

$\checkmark \quad$ : activities mechanized; X: activities not mechanized

Source: Field survey, 2017

Table 5: Marketing functions carried out by intermediaries

\begin{tabular}{lllll}
\hline Intermediaries & Functions carried out & F & $\%$ & Utility added \\
\hline Processors & Processing & 108 & 100 & Form \\
& Storage & 98 & 90.7 & Time \\
& Distribution & 95 & 88 & Place \\
& Negotiation and sales & 108 & 100 & $\begin{array}{l}\text { Change of } \\
\text { ownership }\end{array}$ \\
& & & & Time \\
Marketers & Storage & 108 & 100 & Place \\
(Wholesalers \& retailers) & Distribution & 108 & 100 & $\begin{array}{l}\text { Change of } \\
\text { ownership }\end{array}$ \\
& $\begin{array}{l}\text { Negotiation for } \\
\text { purchases and sales }\end{array}$ & 108 & 100 & \\
\hline
\end{tabular}

Source: Field survey, 2017

Table 6: Palm oil sales at the farm gate by individual processors

\begin{tabular}{lllc}
\hline Seller & Buyers & Frequency & Percentage* \\
\hline Processor & Retailers & 106 & 98.1 \\
Processor & Consumers & 78 & 72.2 \\
Processor & Wholesalers & 66 & 61.1 \\
\hline
\end{tabular}

*Multiple Responses recorded

Source: Field survey, 2017

Journal of the Faculty of Agriculture and Veterinary Medicine, Imo State University Owerri website: www ajol.info 


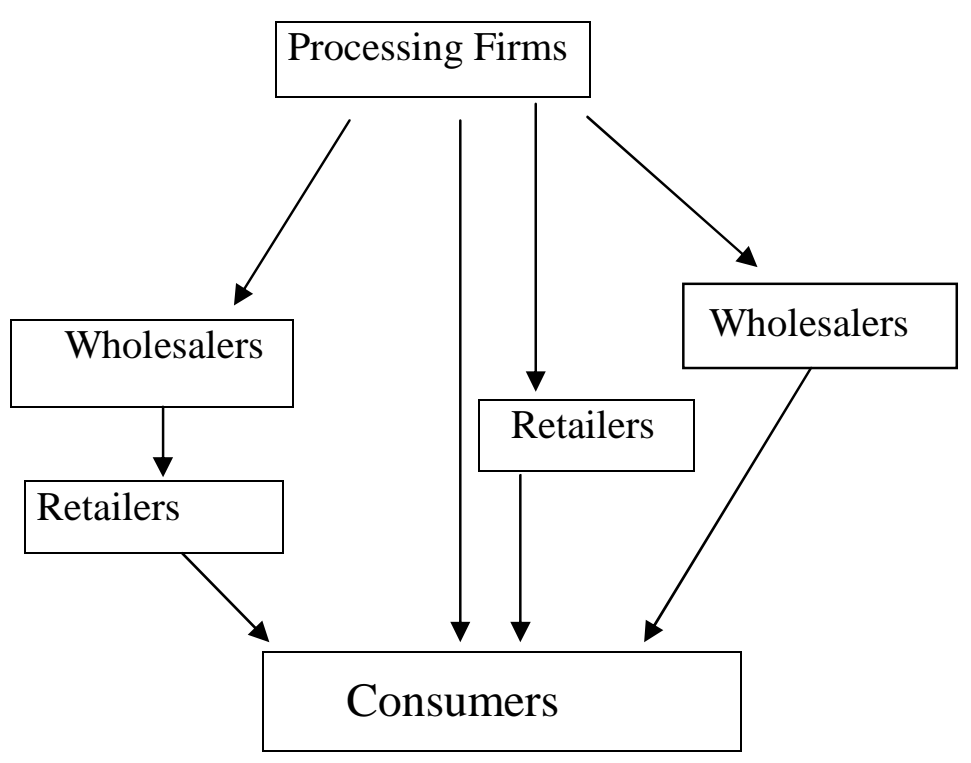

Figure 2: Marketing channels of processing firms

Source: Field Survey, 2017

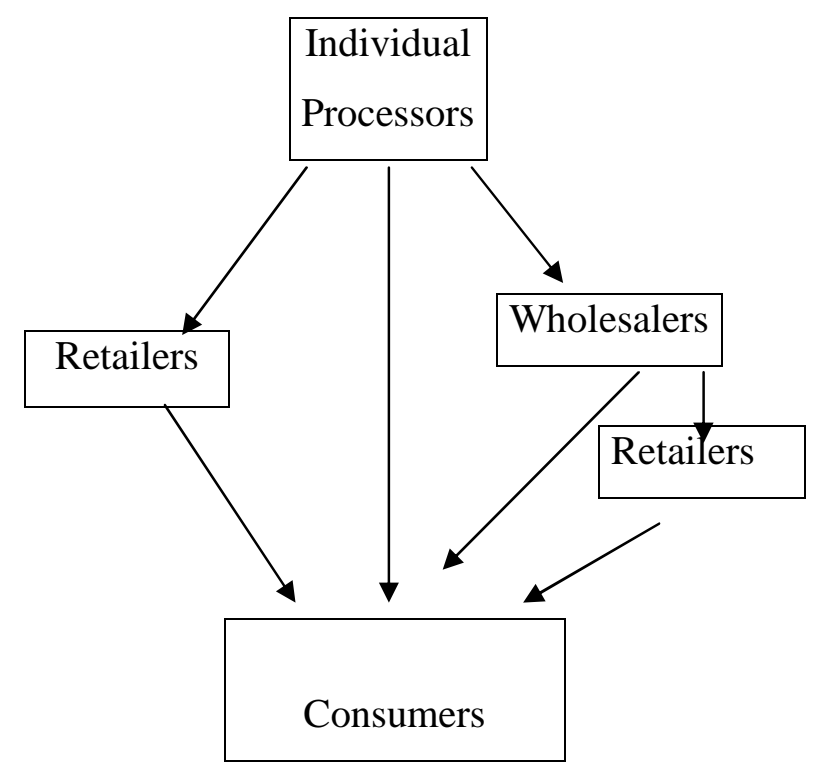

Fig.1: Marketing channels of individual processors

Source: Field Survey, 2017

Journal of the Faculty of Agriculture and Veterinary Medicine, Imo State University Owerri website: www ajol.info 
Table 7: Average profitability of processing 1000 fresh fruit bunch by individual processors

\begin{tabular}{|c|c|c|c|}
\hline Items & Quantity & Revenue/cost (N) & Amount (N) \\
\hline \multicolumn{4}{|l|}{ Revenue } \\
\hline Palm oil @ $\$ 135 /$ litre & 2021 litres & 272,835 & \\
\hline Palm kernel nut @ $\$ 35.04 / k g$ & $450 \mathrm{~kg}$ & 15,768 & \\
\hline Total Revenue (TR) & & & 288,603 \\
\hline \multicolumn{4}{|l|}{ Cost } \\
\hline \multicolumn{4}{|l|}{ Variable cost } \\
\hline Fresh fruit bunch @ N125/FFB & $1000 \mathrm{FFB}$ & 125,000 & \\
\hline Transportation & & 70,000 & \\
\hline Knocking out fruits & & 3,000 & \\
\hline Loading of fruits & & 2,500 & \\
\hline Boiling & & 5,000 & \\
\hline Milling and oil extraction & & 9,000 & \\
\hline Packaging and storage & & 8,000 & \\
\hline Miscellaneous & & 1,200 & \\
\hline Total Variable Cost (TVC) & & & 223,700 \\
\hline \multicolumn{4}{|l|}{ Fixed Cost } \\
\hline Processing machine* & 10,000 & & \\
\hline Vessels and others $*$ & 5,000 & & \\
\hline Rent & 10,000 & & \\
\hline Total Fixed Cost (TFC) & & & 25,000 \\
\hline Total cost $(\mathrm{TC})=(\mathrm{TVC}+\mathrm{FC})$ & & & 248,700 \\
\hline Net profit $(\mathrm{NP})=(\mathrm{TR}-\mathrm{TC})$ & & & 39,903 \\
\hline Return on Investment (NP/TC) & & & 0.16 \\
\hline
\end{tabular}

Source: Field survey 2017

*Depreciation (using straight line method) 
Table 8: Average profitability of processing 1000 fresh fruit bunch by each processing firm Items of revenue/ cost

\section{Quantity} (\$)

\section{Revenue}

Palm oil @ $\$ 135 /$ litre

Palm kernel nut @ $\$ 35.04 / \mathrm{kg}$

Total revenue (TR)

Cost

Variable cost (VC)

1000fb at N125/ffb

Transportation

Knocking out fruits

Loading

Boiling, milling and oil extraction

Packaging and storage

Miscellaneous

Total VC

\section{Fixed Cost}

Processing machine

Vessels and others

Rent

Total Fixed Cost

Total cost $(\mathrm{TC})=(\mathrm{TVC}+\mathrm{FC})$

Net profit $(\mathrm{NP})=(\mathrm{TR}-\mathrm{TC})$

Return on investment $=(\mathrm{NP} / \mathrm{TC})$

Source: Field survey 2017

*Depreciation (using straight line method)

$\begin{array}{lll}2295 \text { litres } & 309,825 & 309,825 \\ 450 \mathrm{~kg} & 15,768 & 15,768 \\ & & \mathbf{3 2 5 , 5 9 3}\end{array}$

125,000

70,000

3,000

2,000

10,800

10,000

3,000

223,800

12,000

2,000

6,000
Amount (N)

$\mathbf{3 2 5 , 5 9 3}$

Table 9: Profitability analysis of marketing 1000 litres of palm oil by intermediaries

\begin{tabular}{|c|c|c|c|}
\hline Revenue/ cost items & Quantity & $\begin{array}{l}\text { Wholesalers } \\
\text { (N) }\end{array}$ & Retailers (N) \\
\hline $\begin{array}{l}\text { Revenue } \\
\text { Palm oil }\end{array}$ & 1000 litres & $\begin{array}{l}\text { 190,000 } \\
@ \$ 190 / \text { litre }\end{array}$ & $\begin{array}{l}\text { 200,000 } \\
@ \approx 200 / \text { litre }\end{array}$ \\
\hline $\begin{array}{l}\text { Cost } \\
\text { Variable cost }\end{array}$ & & & \\
\hline $\begin{array}{l}\text { Palm oil } \\
\text { Transportation }\end{array}$ & 1000 litres & $\begin{array}{l}140,000 \\
@ ® 140 / \text { litre } \\
3,500\end{array}$ & $\begin{array}{c}150,000 \\
@ 150 / \text { litre } \\
3,800\end{array}$ \\
\hline
\end{tabular}

Journal of the Faculty of Agriculture and Veterinary Medicine, Imo State University Owerri website: www ajol.info 


\begin{tabular}{lcc}
\hline Storage/preservation & 3,100 & 2,050 \\
Telephone calls & 1,000 & 300 \\
Feeding & 500 & 300 \\
Miscellaneous & 500 & 400 \\
TVC & $\mathbf{1 4 8 , 6 0 0}$ & $\mathbf{1 5 6 , 8 5 0}$ \\
Fixed cost & 500 & 400 \\
Rent & 700 & 400 \\
Interest & \multicolumn{2}{c}{850} \\
Depreciation of & 1000 & $\mathbf{1 , 6 5 0}$ \\
Vessels and containers & $\mathbf{2 , 2 0 0}$ & $\mathbf{1 5 8 , 5 0 0}$ \\
TFC & $\mathbf{1 5 0 , 8 0 0}$ & $\mathbf{4 1 , 5 0 0}$ \\
Total marketing cost (TMC) $=$ & $\mathbf{3 9 , 2 0 0}$ & $\mathbf{7 9 . 3}$ \\
(TVC + FC) & 79.4 & \\
Net profit (NP) $=($ Rev - TMC) & & \\
Marketing Efficiency (ME) $=$ & TMC/Rev) x 100\% &
\end{tabular}

Source: Field survey data, 2017.

Table 10: Regression results of the effect of socio-economic characteristics of individual oil palm fruit processor on net returns

\begin{tabular}{lllll}
\hline Variables & $\begin{array}{l}\text { Linear } \\
(\text { t-ratio) }\end{array}$ & $\begin{array}{l}\text { Semi-log } \\
(\text { t-ratio) }\end{array}$ & $\begin{array}{l}\text { Double-log } \\
(\text { t-ratio) }\end{array}$ & $\begin{array}{l}\text { Exponential } \\
(\text { t-ratio) }\end{array}$ \\
\hline Constant & 1030.229 & -9619.118 & 5.709 & 7.623 \\
& $(1.386)$ & $(-3.549)^{\mathrm{xxx}}$ & $\left(6.588^{\mathrm{xxx}}\right.$ & $(28.561)^{\mathrm{xxx}}$ \\
Gender $\left(\mathrm{X}_{1}\right)$ & 2034.145 & 3490.868 & 1.378 & 0.579 \\
& $(10.357)^{\mathrm{xxx}}$ & $(6.450)^{\mathrm{xxx}}$ & $(7.964)^{\mathrm{xxx}}$ & $(8.207)^{\mathrm{xxx}}$ \\
Marital status $\left(\mathrm{X}_{2}\right)$ & 1086.583 & 1845.163 & 1.108 & 0.459 \\
& $(4.669)^{\mathrm{xxx}}$ & $(2.887)^{\mathrm{xxx}}$ & $(5.421)^{\mathrm{xxx}}$ & $(5.495)^{\mathrm{xxx}}$ \\
Age $\left(\mathrm{X}_{3}\right)$ & 11.735 & 1403.251 & 0.012 & -0.002 \\
& $(0.825)$ & $(2.011)^{\mathrm{xxx}}$ & $(0.055)$ & $(-0.392)$ \\
Education $\left(\mathrm{X}_{4}\right)$ & 38.625 & 1282.843 & 0.088 & 0.005 \\
& $(1.169)$ & $(4.421)^{\mathrm{xxx}}$ & $(0.951)$ & $(0.396)$ \\
Experience $\left(\mathrm{X}_{5}\right)$ & 7.997 & 29.383 & -0.053 & -0.004 \\
& $(0.747)$ & $(0.175)$ & $(-0.981)$ & $(-0.953)$ \\
$\mathrm{R}^{2}$ & 0.551 & 0.441 & 0.471 & 0.471 \\
$\mathrm{R}^{-2}$ & 0.529 & 0.414 & 0.445 & 0.446 \\
$F^{2}-$ ratio & $25.013^{\mathrm{xxx}}$ & $16.103^{\mathrm{xxx}}$ & $18.144^{\mathrm{xxx}}$ & $18.200^{\mathrm{xxx}}$ \\
\hline
\end{tabular}

Source: Computed from field survey data, 2017

$*^{* * * *}=$ significant at $1 \%$

Journal of the Faculty of Agriculture and Veterinary Medicine, Imo State University Owerri website: www ajol.info 
Table 11: Regression results of the effect of Socio-economic characteristics of palm oil marketers on their net income

\begin{tabular}{lllll}
\hline Variables & $\begin{array}{l}\text { Linear } \\
(\text { t-ratio) }\end{array}$ & $\begin{array}{l}\text { Semi-log } \\
\text { (t-ratio) }\end{array}$ & $\begin{array}{l}\text { Double-log } \\
\text { (t-ratio) }\end{array}$ & $\begin{array}{l}\text { Exponential } \\
(\text { t-ratio) }\end{array}$ \\
\hline Constant & -433.378 & 11773.767 & 7.877 & 8.689 \\
& $(-0.058)$ & $(0.491)$ & $(7.242)^{\mathrm{xxx}}$ & $(12.400)^{\mathrm{xxx}}$ \\
Gender $\left(\mathrm{X}_{1}\right)$ & -4730.659 & -11213.258 & -0.412 & -0.211 \\
& $(-1.348)$ & $(-1.232)$ & $(-0.999)$ & $(-1.281)$ \\
Marital status $\left(\mathrm{X}_{2}\right)$ & 1843.136 & 2270.004 & -0.220 & 0.023 \\
& $(0.508)$ & $(-0.240)$ & $(-0.513)$ & $(0.138)$ \\
Age $\left(\mathrm{X}_{3}\right)$ & -200.510 & -8474.660 & -0.304 & -0.008 \\
& $(-1.374)$ & $(-1.515)$ & $(-1.197)$ & $(-1.292)$ \\
Education $\left(\mathrm{X}_{4}\right)$ & 2835.140 & 22277.333 & 1.413 & 0.172 \\
& $(7.462)^{\mathrm{xxx}}$ & $(7.012)^{\mathrm{xxx}}$ & $(9.809)^{\mathrm{xxx}}$ & $(9.869)^{\mathrm{xxx}}$ \\
Experience $\left(\mathrm{X}_{5}\right)$ & 186.027 & 1818.808 & 0.171 & 0.007 \\
& $(1.309)$ & $(1.006)$ & $(2.085)^{\mathrm{xxx}}$ & $(1.099)$ \\
$\mathrm{R}^{2}$ & 0.453 & 0.414 & 0.572 & 0.577 \\
$\mathrm{R}^{-2}$ & 0.426 & 0.385 & 0.551 & 0.556 \\
F-ratio & $16.896^{\mathrm{xxx}}$ & $14.402^{\mathrm{xxx}}$ & $27.264^{\mathrm{xxx}}$ & $27.773^{\mathrm{xxx}}$ \\
\hline
\end{tabular}

$* * *=$ significant at $1 \%$

Source: Computed from field survey data, 2017 